\title{
FOREWORD / AVANT-PROPOS
}

\section{Maintaining Arthropods in Northern Forest Ecosystems: Symposium Proceedings}

Ratification of the Convention on Biological Diversity by Canada and many other countries in 1992 was followed by a period of increasing focus on biodiversity science worldwide. In response to the Convention, Canada developed a national Biodiversity Strategy and commenced its implementation in 1995. The central tenet of the Canadian strategy is that conservation of biodiversity and sustainable use of biological resources are fundamental to human well-being. In the forest sector, much research attention has been focused on assessing impacts of forest management on biodiversity, and development of "best practices" to maintain biodiversity on managed landscapes. In particular, terrestrial arthropods have become increasingly popular subjects of study, as their high species richness, diversity of trophic roles and habitats, sensitivity to environmental disturbances, and ease of sampling make them ideal indicators for assessment of forest ecosystem impacts and recovery. Furthermore, work on landscapes long managed for forest production in northern Europe shows that arthropod communities are vulnerable to impact.

The large variety and volume of science focused on forest arthropod biodiversity in Canada and adjacent parts of the United States of America over the last 15 years provides a solid foundation on which to build future research initiatives. However, informal discussions within the research community have suggested that the effectiveness and relevance of future work on forest arthropod biodiversity would be enhanced by a review and synthesis of work to date. To meet this need, the Biological Survey of Canada (Terrestrial Arthropods) organized a symposium, "Maintaining Arthropods in Northern Forest Ecosystems", which was held on 4 November 2005 during the annual meeting of the Entomological Society of Canada in Canmore, Alberta. Symposium contributors reviewed and synthesized information about structure and dynamics of arthropod assemblages from managed North American forests (mainly boreal and north temperate). The symposium was designed

\section{Actes du symposium : Maintien des arthropodes dans les écosystèmes forestiers nordiques}

La ratification de la Convention sur la diversité biologique par le Canada et de nombreux autres pays en 1992 a suscité un intérêt accru à l'égard de la science de la biodiversité à l'échelle mondiale. Dans la foulée de la Convention, le Canada a élaboré une Stratégie canadienne de la biodiversité et a entrepris de la mettre en ouvre en 1995. Cette stratégie s'appuie sur le principe selon lequel la conservation de la biodiversité et l'exploitation durable des ressources biologiques sont essentielles au bien-être de l'humanité. Dans le secteur forestier, les chercheurs ont accordé une attention toute particulière à l'évaluation des impacts des pratiques de gestion forestière sur la biodiversité et à la mise au point de bonnes pratiques permettant de mieux préserver la biodiversité à l'échelle des paysages perturbés. Les arthropodes terrestres, du fait de leur grande richesse spécifique, de la diversité de leurs rôles trophiques et de leurs habitats, de leur sensibilité aux perturbations anthropiques et de la facilité avec laquelle ils peuvent être échantillonnés, sont devenus des sujets de recherche de plus en plus populaires et sont considérés comme des indicateurs idéaux pour l'évaluation des impacts sur les écosystèmes forestiers et le rétablissement de ces mêmes écosystèmes. Enfin, des travaux effectués dans le nord de l'Europe sur des paysages faisant l'objet depuis de nombreuses années d'une gestion axée sur l'exploitation ont montré que les communautés d'arthropodes sont vulnérables aux impacts des pratiques forestières.

La diversité et le volume des travaux scientifiques consacrés à la biodiversité des arthropodes forestiers au Canada et dans les régions adjacentes des États-Unis au cours des 15 dernières années constituent une base solide pour les recherches à venir. Toutefois, des discussions informelles avec des membres de la communauté scientifique donnent à croire qu'un examen et une synthèse des travaux réalisés à ce jour contribueraient à accroître l'efficacité et la pertinence des futures recherches sur la biodiversité des arthropodes forestiers. À cette fin, la Commission biologique du Canada (Arthropodes terrestres) a parrainé un symposium intitulé " Maintien des arthropodes dans les écosystèmes forestiers nordiques » dans le cadre de la 
to address forest-biodiversity issues in Canadian forests with special emphasis on the continental boreal and cordilleran ecozones. Thus, a large volume of work from northern Europe is highly relevant to the synthesis presented but little attention is given to studies in tropical, subtropical, and temperate zones despite their abundance and importance.

The symposium included seven papers, six of which synthesized information about specific arthropod groups. The authors were asked to address the following questions:

- What are the spatial/temporal patterns in species richness and assemblage composition, as influenced by geography, forest type, forest succession, etc.?

- How do assemblages respond to anthropogenic disturbances (especially harvesting) and natural disturbances (e.g., wildfire)?

- What species or kinds of species (e.g., in terms of dispersal ability, trophic group) are most threatened by forest management?

- What are the best conservation measures (i.e., how harvesting could be adapted) for ensuring that these organisms are maintained on forested landscapes?

- What are the critical gaps that need to be addressed and how should they be prioritized?

The first paper focuses on ground beetles (Coleoptera: Carabidae), the arthropod group that has received probably the most research attention in forest-biodiversity science in Canada. Therein, Tim Work et al. examine the results from 10 large-scale studies from across Canada and assess the potential of carabid beetles as effective bioindicators of forest management. Greg Pohl et al. summarize and synthesize information on epigaeic rove beetles (Coleoptera: Staphylinidae), based largely on data from seven studies in Canada. Chris Buddle and David Shorthouse report about spiders (Arachnida: Araneae), an increasingly well-studied epigaeic group, and compare the responses of assemblages to partial harvesting treatments across large-scale experiments in Alberta and Quebec. David Langor et $a l$. focus on the hyperdiverse assemblages of beetles associated with dead wood (i.e., the saproxylic fauna), review the determinants of assemblage structure, and summarize the impacts of wildfire and harvesting on assemblage composition and structure. Keith Summerville and Thomas Crist review the literature about multiscale patterns of moth (Lepidoptera) species richness and community composition in northeastern forest ecosystems, and examine community réunion annuelle de la Société entomologique du Canada, le 4 novembre 2005, à Canmore (Alberta). Les participants à ce symposium ont passé en revue et synthétisé l'information disponible sur la structure et la dynamique des assemblages d'arthropodes des forêts sous aménagement d'Amérique du Nord (principalement des zones boréale et tempérée du Nord). Le symposium visait à examiner les enjeux liés à la biodiversité forestière dans les forêts canadiennes, en particulier dans les écozones continentales boréale et cordillérienne. En conséquence, les nombreux travaux réalisés dans le nord de l'Europe ont été jugés très pertinents aux fins de cet exercice de synthèse, tandis que les études réalisées en régions tropicales, subtropicales et tempérées ont reçu peu d'attention, en dépit de leur abondance et de leur importance.

Sept articles ont alors été examinés, dont six résumant les informations disponibles sur des groupes d'arthropodes particuliers. Leurs auteurs ont été invités à examiner les questions suivantes :

- Comment la géographie, la composition forestière, la succession forestière et d'autres facteurs influent-ils sur l'évolution spatio-temporelle de la richesse et de la composition des assemblages d'espèces ?

- Comment les assemblages d'espèces réagissent-ils aux perturbations anthropiques (en particulier l'exploitation forestière) et naturelles (p. ex. feux de forêt) ?

- Quelles espèces ou types d'espèces (par exemple en terme de capacité de dispersion, groupe trophique) sont les plus menacés par l'aménagement forestier?

- Quelles mesures de conservation devrait-on préférablement mettre en place (i.e., comment les pratiques d'exploitation peuvent être adaptées) pour assurer le maintien de ces organismes dans les paysages forestiers ?

- Quelles sont les principales lacunes à combler et comment devrait-on en établir l'ordre de priorité ?

Le premier article porte sur les carabes (Coleoptera : Carabidae), probablement le groupe d'arthropodes le plus largement étudié par les spécialistes de la biodiversité forestière au Canada. Dans cet article, Tim Work et al. examinent les résultats de dix études à grande échelle réalisées dans diverses régions du Canada et évaluent l'utilité des carabes comme bioindicateurs des pratiques d'aménagement forestier. Greg Pohl et al. résument et synthétisent les informations disponibles sur les staphylins épigés (Coleoptera : Staphylinidae) en se fondant principalement sur les données provenant de sept études réalisées au 
responses to harvesting and habitat fragmentation. John Richardson turns our attention to aquatic systems and demonstrates that these freshwater invertebrate assemblages are also affected by forest-harvesting operations and that there are opportunities to manage such effects. Finally, John Spence et al. set the context for work about forest biodiversity in Canada and identify themes and challenges common to the Canadian research community. They also map the six preceding papers into a Canadian context, assessing research gaps and identifying significant opportunities for both research and more effective implementation of the Canadian biodiversity strategy.

We thank our contributors for their patience through the longer-than-intended process of getting the symposium into print. On behalf of all contributors we extend our gratitude to Richard Ring and Robb Bennett for facilitating the publication of this symposium in The Canadian Entomologist. We offer special thanks to Hugh Danks for his constant interest and encouragement.

\section{David Langor \\ Canadian Forest Service, Natural Resources Canada Edmonton, Alberta}

\section{John Spence}

Department of Renewable Resources, University of Alberta, Edmonton, Alberta
Canada. Chris Buddle et David Shorthouse s'intéressent aux araignées (Arachnida : Araneae), groupe d'arthropodes épigés de plus en plus étudié, et comparent les réactions d'assemblages d'espèces à divers régimes de coupes partielles observées dans le cadre d'expériences à grande échelle conduites en Alberta et au Québec. David Langor et al. examinent les facteurs qui influent sur la structure des assemblages extrêmement diversifiés de coléoptères associés au bois mort (saproxylophiles) et décrivent brièvement les impacts des feux de forêt et de l'exploitation forestière sur la composition et la structure de ces mêmes assemblages. Keith Summerville et Thomas Crist examinent la littérature portant sur les tendances multi-échelles de la richesse spécifique et de la composition des communautés de papillons de nuit (Lepidoptera) dans les écosystèmes forestiers du nord-est de l'Amérique du Nord et analysent les réactions de ces communautés aux coupes forestières et à la fragmentation de l'habitat. John Richardson s'intéresse aux écosystèmes aquatiques et démontre que les assemblages d'invertébrés d'eau douce sont également touchés par les pratiques d'exploitation forestière et que les impacts de ces pratiques peuvent être gérés. Enfin, John Spence et al. précisent le contexte dans lequel doit être menée la recherche sur la biodiversité forestière au Canada et identifient certains thèmes et enjeux communs à la communauté canadienne de la recherche. Ils resituent les six articles précédents dans un contexte canadien, passent en revue les lacunes dans le domaine de la recherche et examinent les principales possibilités en ce qui a trait à la recherche et à l'application plus efficace de la stratégie canadienne de la biodiversité.

Nous remercions nos collaborateurs de leur patience durant le processus plus long que prévu qui a mené à la publication des actes du symposium. Au nom de tous nos collaborateurs, nous remercions Richard Ring et Robb Bennett d'en avoir facilité la publication dans la revue The Canadian Entomologist. Nous remercions tout particulièrement Hugh Danks de son appui constant et de ses encouragements.

\section{David Langor}

Service canadien des forêts, Ressources naturelles Canada Edmonton (Alberta)

\section{John Spence}

Département des ressources renouvelables, Université de l'Alberta, Edmonton (Alberta) 